\title{
Sport management research - an integral part of sport science?
}

\author{
Martin Schnitzer ${ }^{1, *}$ \& Martin Kopp \\ 1 Department of Sport Science, University of Innsbruck, Innsbruck, Austria \\ * Corresponding author: Department of Sport Science, University of Innsbruck, Fürstenweg 185, A-6020 Innsbruck, Austria, \\ Tel: +43 (0) 512-507-45865, Fax: +43 (0) 512-45999, \\ Email: Martin.Schnitzer@uibk.ac.at
}

\section{REPORT}

\section{Article History:}

Published $2^{\text {nd }}$ February 2018

Editor-in-Chief:

Martin Kopp

University of Innsbruck, Austria

\begin{abstract}
CURRENT ISSUES IN SPORT SCIENCE (CISS) has published in the last year 50\% of the research articles in the section 'sociology \& economics'. The topics of these recently published articles in CISS show the importance and diversity of this area of research. The growing body of research in sport management has demonstrated that this scientific field has become a relevant piece in the interdisciplinary mosaic of sport science. In the future, these contributions might lead to an increase of sport management divisions within the departments of sport science to satisfy the growing demand of sport management related education.
\end{abstract}

Keywords:

Sociology \& economics - sport management - sport science - research - impact

Citation:

Schnitzer, M. \& Kopp, M. (2018). Sport management research - an integral part of sport science? Current Issues in Sport Science, 3:001. doi: 10.15203/ CISS_2018.001

In the last year CISS published 50\% of the research articles in the section 'sociology \& economics'; some more are currently under review. This field of research seems to become more popular amongst scholars publishing in our journal and, therefore this editorial is dedicated to aspects related to aspects related to research in sociology of sports economics and sport management.

Almost every handbook in sport management and/or sports economics states that the history of this research area started with the study of Rottenberg, (1956), analyzing the baseball players' labor market. It highlights the uncertainty-of-outcome hypothesis, which has become relevant for scholars searching in this field. Nevertheless, sport management's jump across the big pond took a while. As revealed by Thieme, (2011), especially within the German-speaking sport science community the discussion on whether sport management can be considered as an own research discipline or whether its mother discipline is sport science or sports economics/business management has not come to an end, yet. Very often, the allocation of sport management depends on the wording and definition (Thieme, 2011). Considering sports economists' area of activ- ity and being aware that the term 'sport management' would be too narrow to discuss also issues of business administration such as accounting, marketing, finance and law (Heinemann, 1998), the word 'sport management' has established itself as a brand (Thöni, 2010). However, as stated by the German Association of Sport Economics and Sport Management, sports economics uses theories and methods from economics as well as business administration, sport science or other social sciences and, therefore, splitting sport economists and sport managers would not be purposeful (Arbeitskreis Sportökonomie, 2018). Two other aspects should be mentioned in this context. Firstly, practice and the demand for sport managers caused an increase in academic programs on bachelor and master level. In Germany over 50 sport management programs are currently offered by academic institutions (Wallrodt \& Thieme, 2017), some of them located in faculties of economics and others in faculties of sport science. The situation in Austria is similar; currently, eight either public or private universities and/or universities of applied sciences offer sport management degrees. Secondly, research in the field of sport management increased in the last years. The importance of the contributions 
to the most relevant sport management journals can also be seen with the impact factor of 2016 in the Web of Science citation reports of the journals published by the continental sport management associations (Sport Management Review: 2.128; European Sport Management Quarterly: 1.778; Journal of Sport Management: 1.247).

Hence, it seems not surprising that researcher approached CISS as a platform for sharing their contributions. In our opinion, the potpourri of articles shedding light on different aspects of the field 'sport sociology - management - economics' is vast and rich of new approaches and shows the diversity of this discipline.

In their review about technological umpiring aids for referees Kolbinger \& Lames, (2017) discussed potential issues future empirical studies will need to manage. Therefore, their review was an important first step for further investigations. By using the International Table Tennis Federation as an example Schubert \& Seyffert (2017) contributed to the understanding of sport fans' motives in the context of social media and revealed potential implications for managers of (niche) sport organizations with limited financial and personal resources. Rullang, Emrich, \& Pierdzioch, (2017) analyzed factors determining the career of referees and reasons for quitting this activity. This research group found out that the duration of a referee career, amongst other factors, depends on whether the referee is successful in coping with insults, threats, and violence. The authors conclude that almost 39\% of former referees mentioned that the end of their referee career could have been prevented. The study of Könecke \& Nooij, (2017) examined the bidding processes for the (Winter) Olympic Games 2022 - 2028 and the decisions taken in democratic countries and authoritarian states. Moreover, Schnitzer, Kristiansen, \& Hanstaad, (2018) compared the expectations, experiences and legacies as perceived by volunteers at two events of the same type (Nordic World Ski Championships) but staged in two different places and two different cultural settings. The results showed, for example, that the retention rate may be higher in Val di Fiemme (WSC 2013) than in Oslo (WSC 2011) due to local community loyalty. Finally, Ruoranen and coworkers (2018) explored causes for professionalization in Swiss national sport federations. The authors found that causes for professionalization were widely similar in the analyzed federations. Furthermore, this study revealed that conflicts on the board, unclear decision-making competences and initiatives of key persons were reasons triggering professionalization.

The variety of articles proves the wide range of sport management-related studies and their concrete practical implications for sports organizations such as major sports event organizers, sports federations but also policy makers in sports or professional sport leagues. As claimed by the society, research should also give concrete benefits and support social progress.

Considering all aspects, the question of what may qualify sport management to become a research discipline as stated by Thieme (2011), hast to be judged by every CISS reader him/herself, but one thing is certain: sport management has become an integral part of the scientific community and should be anchored in sport science as outlined in the opening editorial of CISS (Kopp, 2016). The proofs are oppressive.

\section{Funding}

The authors have no funding or support to report.

\section{Competing Interests}

The author's role for CISS is Editor-in-Chief (2016-2020) and Founding Editor (2015).

\section{Data Availability Statement}

All relevant data are within the paper.

\section{References}

Arbeitskreis Sportökonomie. (2018). Strategie des Arbeitskreises Sportökonomie. Retrieved from http://www.arbeitskreis-sportoekonomie.de/html/strategie_des_arbeitskreises.html

Heinemann, K. (1998). Sportwissenschaft: Was ist und wozu benötigen wir eine Sportökonomik? (28th ed., 3-4).

Kolbinger, O., \& Lames, M. (2017). Scientific approaches to technological officiating aids in game sports. Current Issues in Sport Science (CISS). Advance online publication. https://doi. org/10.15203/CISS_2017.001

Könecke, T., \& Nooij, M. de. (2017). The IOC and Olympic bids from democracies and authoritarian regimes - A socioeconomic analysis and strategic insights. Current Issues in Sport Science (CISS), 2. https://doi.org/10.15203/CISS_2017.009

Kopp, M. (2016). Why a new sport science journal? Current Issues in Sport Science (CISS), 1. https://doi.org/10.15203/ CISS_2016.002

Rottenberg, S. (1956). The Baseball Players' Labor Market. Journal of Political Economy, 64(3), 242-258. https://doi. org/10.1086/257790

Rullang, C., Emrich, E., \& Pierdzioch, C. (2017). Why do referees end their careers and which factors determine the duration of a referee's career? Current Issues in Sport Science (CISS), 2, 1-13. https://doi.org/10.15203/CISS_2017.006

Ruoranen, K., Clausen, J., Nagel S. , Lang, G., Klenk, C., Giauque, C., Bayle E. \& Schlesinger, T. (2018): Causes for professionalization in national sport federations in Switzerland: a multiple-case study. Current Issues in Sport Science (CISS), 3:001. doi: 10.15203/CISS_2018.001

Schnitzer, M., Kristiansen, E., \& Hanstad, D. V. (2018). Comparing the expectations, experiences and legacies of volunteers at the FIS Nordic World Ski Championships in Oslo 2011 and 
Val di Fiemme 2013. Current Issues in Sport Science (CISS), 3. https://doi.org/10.15203/CISS_2018.002

Schubert, M., \& Seyffert, J. (2017). Fan motives for interacting on social media - the example of the International Table Tennis Federation and Facebook. Current Issues in Sport Science (CISS), 2, 1-11. https://doi.org/10.15203/CISS_2017.004

Thieme, L. (2011). Zur Konstitution des Sportmanagements als Betriebswirtschaftslehre des Sports: Entwicklung eines Forschungsprogramms. Zugl.: Saarbrücken, Univ., Habil.-Schr (1. Aufl.). Edition Sport, Ökonomie, Wissenschaft: Vol. 1. Berlin: Epubli.

Thöni, E. (2010). Europäische Sportökonomie - quo vadis? 1. Innsbrucker Sporökonomie- und Management Symposium, 17.03.2011.

Wallrodt, S., \& Thieme, L. (2017). Arbeitsmarkt und Sport - eine ökonomische Betrachtung: Sport Labor Economics. Sportökonomie: Vol. 19. Schorndorf: Hofmann. 